\title{
UPAYA HUKUM DALAM PERKARA KEPAILITAN
}

\author{
Drs Munif Rochmawanto, SH,MH,MM
}

\begin{abstract}
Abstrak
Pailit sebagaimna tercermin dalam pasal 2 ayat (1) Undang Undang Nomor .37 tahun 2004 adalah suatu keadaan dimana debitor tidak membayar lunas sedikitnya satu utang yang telah jatuh waktu dan dapat ditagih dan dinyatkan pailit dengan putusan pengadilan. Dalam putusan pengadilan tentunya ada pihak-pihak yang merasa tidak puas dengan putusan pengadilan terutama pada pihak yang kalah sehingga ada peluang upaya hukum.

Dalam Undang-undang Kepailitan terdapat dua kemungkinan upaya hukum yang dapat ditempuh oleh para pihak yang tidak puas terhadap putusan pernyataan pailit, yaitu upaya kasasi atau peninjauan kembali ke Mahkamah Agung. (pasal 11 ayat (1), pasal 14, pasa 295 ayat (1) UU No.37/2004)1
\end{abstract}

\section{Kata Kunci : Pailit}

\section{A. PENDAHULUAN}

\section{Latar Belakang Masalah}

Pembangunan hukum nasional dalam rangka mewujudkan masyarakat adil dan makmur berdasarkan Pancasila dan Undang-Undang Dasar Negara Republik Indonesia tahun 1945 diarahkan pada terwujudnya sistem hukum nasional yang dilakukan dengan pembentukan hukum baru, khususnya produk hukum yang dibutuhkan untuk mendukung pembangunan perekonomian nasional.

Produk hukum nasional yang menjamin kepastian, ketertiban, penegakan, dan perlindungan hukum yang berintikan keadilan dan kebenaran diharapakan mampu mendukung pertumbuhan dan perkembangan perekonomian nasional, serta mengamankan dan mendukung hasil pembangunan nasional.

$\begin{array}{lcr}\text { Salah } & \text { satu } & \text { hukum yang } \\ \text { diperlukan } & \text { dalam } & \text { menunjang } \\ \text { pembangunan } & \text { perekonomian nasional }\end{array}$

adalah peraturan tentang kepailitan, dan penundaan kewajiban pembayaran hutang yang semula diatur dalam peraturan kepailitan (faillisementverordening, staatsblad 1905:217 juncto staatsblad 1906:348).

Krisis moneter yang melanda negara di belahan asia termasuk Indonesia sejak pertengahan tahun 1997 telah menimbulkan kesulitan besar terhadap perekonomian dan perdagangan nasional. Kemampuan dunia usaha dalam mengembangkan usahanya sangat terganggu, bahkan untuk mempertahankan kelangsungan kegiatan usahanya juga tidak mudah. Hal tersebut sangat mempengaruhi kemampuan untuk memenuhi kewajiban pembayaran utangnya. Keadaan tersebut berakibat timbulnya masalah-masalah yang berantai, yang apabila tidak segera diselesaikan akan berdampak lebih luas, anatara lain hilangnya lapangan kerja dan permasalahan sosial lainnya. 
Untuk kepentingan dunia usaha dalam menyelesaikan masalah utang-piutang secara adil, cepat, terbuka, dan efektif sangat diperlukan perangkat hukum yang mendukungnya. Pada tanggal 22 April 1998 berdasarkan pasal 22 ayat (1) Undang-Undang Dasar 1945 telah dikeluarkan Peraturan Pemerintah Pengganti Undang-Undang tentang kepailitan, yang kemudian ditetapkan menjadi undang-undang dengan Undang-Undang Nomor 4 Tahun 1998. Perubahan dilakukan oleh karena peraturan tentang kepailitan (faillisement-verordening, staatsblad 1905:217 juncto staatsblad 1906:348) yang merupakan peraturan perundangundangan peninggalan pemerintahan Hindia-Belanda sudah tidak sesuai lagi dengan kebutuhan dan perkembangan hukum masyarakat untuk penyelesaian utang-piutang. ${ }^{25}$

Sebagaimana diketahui bahwa proses kepailitan adalah suatu proses pelaksanaan ketentuan pasal 1131 dan pasal 1132 KUH Perdata yang bertujuan untuk membagi harta kekayaan debitur secara adil, dimaksudkan agar kreditur memperoleh pelaksanaan secara mendahului (pari passa) dari yang lain, maupun kreditur memperoleh pelunasan lebih besar terhadap lainnya (protata). ${ }^{26}$

Sebagai catatan perlu juga diketahui bahwa dalam sejarahnya, sebelum kita merdeka peraturan

${ }^{25}$ Hadi Setia Tunggal; UU Kepailitan dan Penundaan Kewajiban Pembayaran Utang. Havarindo Jakarta 2005:h.124-126.

${ }^{26}$ Kartini Mulyadi dan Gunawan Widjaya, Pedoman Menangani Perkara Kepailitan. Raja Grafindo Persada Jakarta. 2003:h.V. kepailitan yang lama sebenarnya tidak berlaku bagi golongan rakyat pribumi. Undang-Undang kepailitan tersebut hanya berlaku bagi golongan Eropa dan golongan Asing. Hal ini sesuai dengan staatsblaad 1924 No. 556 dan staatsblaad 1917 No. 129. Perubahan atas undang-undang kepailitan (faillisement-verordening staatsblad 1905:217 juncto staatsblad 1906:348) ditetapkan dalam bentuk Perpu pada tanggal 22 April 1998 yaitu Perpu No. 1 Tahun 1998 tentang perubahan atas undang-undang kepailitan. Perpu tersebut kemudian menjadi UndangUndang No. 4 Tahun 1998. Dalam masa-masa itu hingga berlakunya revisi atas undang-undang kepailitan, urusan kepailitan merupakan suatu hal yang jarang muncul ke permukaan. Kekurang populeran masalah kepailitan ini terjadi karena selama ini banyak pihak yang kurang puas terhadap pelaksanaan kepailitan. Banyak urusan kepailitan yang tidak tuntas, lamanya waktu persidangan yang diperlukan, tidak adanya kepastian hukum yang jelas, merupakan beberapa dari sekian banyak alasan yang ada. Secara psikologis mungkin hal ini dapat diterima , karena pernyataan kepailitan diartikan hilangnya nilai piutang karena harta kekayaan debitur yang dinyatakan pailit itu tidak mencukupi untuk menutupi semua kewajibannya kepada kreditur. Akibatnya dalam masalah kepailitan, tidak semua kreditur setuju dan bahkan ada yang berusaha keras untuk menentangnya. ${ }^{27}$

Akan tetapi dengan disyahkannya Undang-Undang Nomor

${ }^{27}$ Ahmad Yani dan Gunawan Widjaya, Seri Hukum Bisnis Kepailitan. Raja Grafindo Persada, Jakarta. 2004:h.3. 
37 Tahun 2004 yang memperbaharui UU Kepailitan lama (UU No. 4 Tahun 1998), maka serta-merta dunia hukum diramaikan oleh diskusi dan kasuskasus kepailitan di pengadilan. Sekarang banyak debitur (baik yang nakal maupun yang jujur) yang mulai was-was untuk dipailitkan. Tetapi tentunya hukum kepailitan yang berlaku sekarang haruslah memenuhi syarat-syarat hukum yang efektif, adil, efesien, cepat, pasti, modern, dan terekam dengan baik.

\section{Perumusan Masalah}

Berdasarkan latar belakang masalah tersebut di atas, penulis mengetengahkan dua permasalahan yaitu sebagai berikut :

1. Pengadilan mana yang berwenang memutus perkara kepailitan?

2. Bagaimana upaya hukum dalam perkara kepailitan menurut Undang-Undang Nomor 37 Tahun 2004 ?

\section{Tujuan Penelitian}

Sejalan dengan rumusan masalah tersebut di atas, maka tujuan penelitian ini adalah sebagai berikut :

1. Untuk mengetahui pengadilan mana yang berwenang memutus perkara kepailitan.

2. Untuk mengetahui bagimana upaya hukum putusan pailit menurut Undang-Undang Nomor 37 Tahun 2004.

\section{B. Kajian Pustaka}

\section{Pengertian Kepailitan}

Secara Etimologi, istilah kepailitan berasal dari kata 'pailit' dan istilah tersebut dikenal di perbendaharaan bahasa yang berbedabeda, yaitu :

- Bahasa Perancis = Faillite

- Bahasa Latin = Failire

- Bahasa Inggris = To Fail atau Bankrupt.

Artinya pemacetan atau pemogokan pembayaran utang. Pengertian pailit tercermin dalam pasal 2 ayat (1) UU No. 37 Tahun 2004, yaitu :

"Debitur yang mempunyai dua atau lebih kreditur dan tidak membayar lunar sedikitnya satu utang yang telah jatuh waktu dan dapat ditagih, dinyatakan pailit dengan putusan pengadilan, baik atas permohonan sendiri maupun atas permohonan satu atau lebih krediturnya."

Dalam ensiklopedia ekonomi keuangan perdagangan disebutkan bahwa yang dimaksudkan dengan pailit atau bangkrut, antara lain adalah seseorang yang oleh suatu pengadilan dinyatakan bankrupt, dan aktivanya atau warisannya telah diperuntukkan untuk membayar hutang-hutangnya.

Pengertian kepailitan secara otentik dirumuskan dalam pasal 1 angka 1 UU No. 37 tahun 2004, yang berbunyi :

"Kepailitan adalah sita umum atas semua kekayaan debitur pailit yang pengurusan dan pemberesannya dilakukan oleh kurator di bawah pengawasan hakim pengawas sebagaimana diatur dalam undang-undang ini., 28

Menurut Black Law Dictionary, pengertian pailit dihubungkan dengan ketidakmampuan

${ }^{28}$ Hadi Setia Tunggal. Op. cit hal.4-5 
untuk membayar dari seorang (debitur) atas utang-utangnya yang telah jatuh tempo. Ketidak mampuan tersebut harus disertai dengan suatu tindakan nyata untuk mengajukan, baik yang dilakukan secara sukarela oleh debitur sendiri, maupun atas permintaan pihak ketiga (di luar debitur). ${ }^{29}$

Untuk memberikan kejelasan mengenai definisi dan pengertian kepailitan maka dalam hal ini penulis akan mengutip beberapa definisi atau pendapat dari para sarjana, sebagai berikut :

a. Memoric Van Toelichting, menyatakan bahwa kepailitan adalah suatu penyitaan berdasarkan hukum atas seluruh harta kekayaan si berutang guna kepentingannya bersama para yang mengutangkan;

b. J.C.T. Simorangkir dan Woerjono Sastropranoto, dalam bukunya Pelajaran Hukum Indonesia, menyatakan bahwa kepailitan adalah suatu beslah exekutorial yang dianggap sebagai hak kebendaan seseorang terhadap barang kepunyaan debitur. $^{7}$

c. Kartono, menyatakan bahwa kepailitan adalah suatu sitaan dan eksekusi atas seluruh kekayaan debitur untuk kepentingan seluruh kreditnya bersamasama, yang pada waktu si debitur dinyatakan pailit mempunyai piutang dan untuk jumlah piutang yang masing-masing kreditur memiliki pada saat itu. ${ }^{30}$

d. Soebekti dalam bukunya Pokok-Pokok Hukum Perdata, berpendapat bahwa kepailitan adalah suatu usaha bersama untuk mendapatkan pembayaran semua berpiutang secara adil. ${ }^{31}$

e. R. Soekardono, dalam bukunya Hukum Dagang jilid I, menyatakan bahwa kepailitan adalah penyitaan umum atas kekayaan si pailit bagi kepentingan semua

h. 11

${ }^{29}$ Ahmad Yani dan Gunawan Widjaja. op.cit

${ }^{7}$ Viktor M. Situmorang, Hendri Soekarso,

Pengantar Hukum Indonesia. Rieneka Cipta,

Jakarta 1994:19-20.

${ }^{31}$ Soebekti, Pokok-Pokok Hukum Perdata,

Intermasa, Jakarta 1994:230. penagihnya, sehingga Balai Harta Peninggalan yang ditugaskan dengan pemeliharaan serta pemberesan boedel dari orang yang pailit. ${ }^{32}$

\section{Syarat-Syarat Kepailitan}

Dalam pasal 2 undang-undang kepailitan No. 37 tahun 2004 menyatakan sebagai berikut :

1) Debitur yang mempunyai dua atau lebih kreditur dan tidak membayar lunas sedikitnya satu utang yang telah jatuh waktu dan dapat ditgih, dinyatakan pailit dengan putusan pengadilan, baik atas permohonannya sendiri maupun atas permohonan satu atau lebih krediturnya.

2) Permohonan sebagaimana dimaksud dalam ayat (1) dapat juga diajukan oleh kejaksaan untuk kepentingan umum.

3) Dalam hal ini debitur adalah bank, permohonan pernyataan pailit hanya dapat diajukan oleh Bank Indonesia.

4) Dalam hal ini debitur adalah perusahaan efek, bursa efek, lembaga kliring dan penjaminan, lembaga penyimpanan dan penyelesaian, permohonan pernyataan pailit hanya dapat diajukan oleh badan pengawas pasar modal.

5) Dalam hal debitur adalah perusahaan asuransi, perusahaan reasuransi, dana pensiun, atau Badan Usaha Milik Negara yang bergerak di bidang kepentingan publik, permohonan pernyataan pailit hanya dapat diajukan oleh menteri keuangan.

Dari ketentuan dalam pasal 2 seperti tersebut di atas, dapat ditarik kesimpulan bahwa syarat-syarat yuridis agar suatu perusahaan dapat dinyatakan pailit adalah sebagai berikut :

1) Adanya hutang;

2) Minimal satu dari hutang sudah jatuh tempo dan dapat ditagih;

3) Minimal satu dari hutang dapat ditagih;

4) Adanya debitur;

${ }^{32}$ R. Soekardono, Hukum Dagang, jilid I, Dian Rakyat; Jakarta 1993:195. 
5) Adanya kreditur;

6) Kreditur lebih dari satu;

7) Pernyataan pailit dilakukan oleh pengadilan khusus yang disebut pengadilan niaga;

8) Permohonan pernyataan pailit diajukan oleh pihak yang berwenang, yaitu :

a. Pihak Debitur;

b. Satu atau lebih kreditur;

c. Jaksa untuk kepentingan umum;

d. Bank Indonesia jika debiturnya bank;

e. Badan Pengawas Pasar Modal jika debiturnya perusahaan efek, lembaga kliring dan penjaminan, lembaga penyimpanan dan penyelesaian;

f. Menteri keuangan jika debiturnya perusahaan asuransi, perusahaan reasuransi, dana pensiun, atau BUMN yang bergerak di bidang kepentingan publik.

9) Dan syarat-syarat yuridis lainnya yang disebutkan dalam undangundang kepailitan;

10) Apabila syarat-syarat terpenuhi, hakim 'menyatakan pailit' bukan 'dapat menyatakan pailit', sehingga dalam hal ini kepada hakim tidak memberikan "judgement" yang luas seperti pada kasus-kasus lainnya. ${ }^{33}$

\section{Para Pihak Yang Terlibat Dalam Proses Kepailitan \\ 1) Pihak Pemohon Pailit}

Menurut pasal 2 undangundang kepailitan Nomor 37 Tahun 2004 maka yang dapat menjadi pemohon dalam suatu perkara pailit adalah salah-satu pihak berikut ini :
a. Pihak Debitur itu sendiri;
b. Salah-satu atau lebih dari pihak Kreditur;
c. Pihak kejaksaan jika menyangkut dengan kepentingan umum;
d. Pihak Bank Indonesia jika debiturnya adalah suatu bank;
e. Pihak Badan Pengawas Pasar Modal jika debiturnya suatu perusahaan efek. Yang dimaksud dengan perusahaan efek, bursa efek, lembaga kliring dan penjaminan, serta lembaga penyimpanan dan penyelesaian. ${ }^{34}$
f. Pihak Menteri Keuangan jika debiturnya perusahaan asuransi, reasuransi, dana pensiun, BUMN yang bergerak di bidang kepentingan publik.

\section{2) Pihak Debitur Pailit}

Pihak debitur pailit adalah pihak yang memohon atau dimohonkan pailit ke pengadilan yang berwenang. Yang dapat menjadi debitur pailit adalah debitur yang mempunyai dua atau lebih kreditur dan tidak membayar sedikitnya satu hutang yang telah jatuh waktu dan dapat ditagih. $^{35}$

\section{3) Hakim Niaga}

Perkara kepailitan pada tingkat pertama diperiksa oleh hakim majelis, tidak boleh hakim tunggal (pasal 301 ayat [1]). Hanya untuk perkara perniagaan lainnya yakni yang bukan perkara kepailitan untuk tingkat pengadilan pertama yang boleh diperiksa oleh hakim tunggal dengan penetapan ketua Mahkamah Agung (pasal 301 
ayat [2]). Hakim Majelis tersebut merupakan hakim-hakim pada pengadilan niaga, yakni hakimhakim Pengadilan Negeri yang telah diangkat menjadi hakim pengadilan niaga berdasarkan keputusan ketua Mahkamah Agung (pasal 301 ayat [2]). Di samping itu juga terdapat "Hakim Ad-hoc" yang diangkat dari kalangan para ahli dengan putusan Presiden atas usul ketua Mahkamah Agung (pasal 302 ayat [3]). Undang-Undang No.37 Tahun 2004.

Sedangkan syarat-syarat untuk dapat diangkat sebagai hakim adalah :

a. Telah berpengalaman sebagai hakim dalam lingkungan peradilan umum;

b. Mempunyai dedikasi dan menguasai pengetahuan di bidang masalah-masalah yang menjadi lingkup kewenangan pengadilan;

c. Berwibawa, jujur, adil, dan berkelakuan tidak tercela;

d. Telah berhasil menyelesaikan program pelatihan khusus sebagai hakim pada pengadilan. (pasal 302 ayat [2] UU Kepailitan).

Seluruh bimbingan, pembinaan, dan pengawasan terhadap jalannya peradilan pengadilan niaga dilakukan oleh Mahkamah Agung. Sehubungan dengan hal itu, ketua Mahkamah Agung mempunyai kewajiban untuk melakukan bimbingan, pembinaan, dan pengawasan terhadap peradilan pengadilan niaga dan mempunyai kewenangan untuk mengambil langkah-langkah dalam rangka penerapan prinsip-prinsip hukum peradilan pada pengadilan niaga.

Prinsip-prinsip hukum dimaksud meliputi :

1. Prinsip kesinambungan, penyelenggaraan persidangan pada pengadilan niaga harus dilakukan secara berkesinambungan;

2. Prinsip persidangan yang baik, hendaknya prosedur persidangan pada pengadilan niaga dilakukan secara cepat, efektif, dan terekam dengan baik;

3. Prinsip putusan yang baik, putusan yang akan dibacakan oleh pengadilan niaga harus sudah dibuat secara tertulis pada saat ditetapkan, serta memuat secar lengkap pertimbangan dan dasar hukum yang mendasari putusan tersebut;

4. Prinsip pengarsipan, agar putusan pengadilan niaga dapat diterbitkan secara berkala, pengarsipan putusan pengadilan niaga yang baik harus terselenggara.

\section{Harta Pailit dan Keberadaan Yang Berada Di Luar Harta Pailit}

Yang disebut dengan harta pailit adalah harta milik debitur yang dinyatakan pailit berdasarkan keputusan pengadilan. Ketentuan pasal 21 UU No. 37 Tahun 2004 secara tegas menyatakan bahwa "kepailitan meliputi seluruh kekayaan debitur pada saat putusan pernyataan pailit diucapkan serta segala sesuatu yang diperoleh selama kepailitan."

Khusus bagi individu atau debitur perorangan yang dinyatakan pailit, seluruh akibat dari pernyataan pailit 
tersebut yang berlaku untuk debitur pailit juga berlaku bagi suami atau istri yang menikah dalam persatuan harta dengan debitur pailit tersebut (pasal 23). Ketentuan ini sejalan dengan pasal 4 ayat (1) juncto pasal 4 ayat (2) yang mewajibkan adanya persetujuan dari suami atau istri, dalam hal seorang debitur yang menikah dengan pencampuran harta ingin mengajukan permohonan kepailitan.

Harta benda yang dikecualikan dari harta pailit menurut ketentuan pasal 22 UU No. 37 tahun 2004 ditetapkan sebagao berikut :

1. Benda, termasuk hewan yang benar-benar dibutuhkan oleh debitur sehubungan dengan pekerjaan, perlengkapannya, alatlat medis yang dipergunakan oleh debitur atau keluarganya, dan bahan makanan untuk 30 (tiga puluh) hari bagi debitur dan keluarganya yang terdapat di tempatnya.

2. Segala sesuatu yang diperoleh debitur dari pekerjaannya sendiri sebagai pengujian dari suatu jabatan atau jasa, sebagai upah, pensiun, uang tunggu atau uang tunjangan, sejauh yang ditentukan oleh hakim pengawas.

3. Uang yang diberikan kepada debitur untuk memenuhi suatu kewajiban memberi nafkah menurut undang-undang.

\section{Metode Penelitian}

\section{Tipe Penelitian}

Tipe penelitian hukum yang dilakukan adalah yuridis normatif (hukum normatif). Metode penelitian hukum normatif adalah suatu prosedur penelitian ilmiah untuk menemukan kebenaran berdasarkan logika keilmuan hukum dari sisi normatif ${ }^{36}$. Oleh karena itu penelitian hukum ini difokuskan untuk mengkaji penelitian hukum tentang kaidah-kaidah atau normanorma dalam hukum positif.

\section{Pendekatan Masalah}

Oleh karena tipe penelitian yang digunakan adalah tipe penelitian yuridis normatif, maka pendekatan masalah yang digunakan adalah pendekatan perundang-undangan (statute approach). Pendekatan tersebut melakukan pengkajian peraturan perundangundangan yang berhubungan dengan pokok permasalahan. Selain itu juga digunakan pendekatan konsep (conseptual approach). Pendekatan konsep ini digunakan dalam rangka untuk memahami konsep-konsep akibat hukum putusan pailit sehingga diharapkan penormaan dalam aturan hukum tidak lagi ada pemahaman yang ambigu dan kabur, sehingga menjadi celah bagi pelaku kepailitan yakni debitur dan kreditur.

\section{Bahan Hukum}

$$
\text { Bahan hukum yang }
$$
dipergunakan dalam penelitian ini adalah sebagai berikut :

a. Bahan hukum Primer, yakni yakni merupakan bahan hukum yang bersifat autoritatif artinya mempunyai otoritas, bahan hukum terdiri dari perundang-undangan, catatan resmi, atau risalah dalam pembuatan perundang-undangan dan putusan hakim. Adapun bahan hukum primer tersebut meliputi: Kitab Undang Undang Hukum Perdata, Kitab Undang Undang Hukum Acara Perdata, Undang

${ }^{36}$ Johnny Ibrahim, Teori Metode Penelitian Hukum Normatif, Banyu Media Publishing, Malang 2005, h.47. 
Undang Nomor 37 Tahun 2004 tentang kepailitan dan penundaan kewajiban pembayaran utang.

b. Bahan Hukum Sekunder, yaitu bahan hukum yang diperoleh dari buku teks, jurnal-jurnal, pendapat para sarjana, dan kasus-kasus hukum.

4. Prosedur Pengumpulan Bahan Hukum

Baik bahan hukum primer maupun bahan hukum sekunder dikumpulkan berdasarkan topik permasalahan yang telah dirumuskan dan diklasifikasikan menurut sumber dan hirarkinya untuk dikaji secara komperehensif.

5. Pengolahan Dan Analisa Bahan Hukum Adapun data yang diperoleh dalam penelitian studi kepustakaan, aturan perundang-undangan, yang penulis uraikan dan dihubungkan sedemikian rupa, sehingga disajikan dalam penulisan yang lebih sistematis guna menjawab permasalahan yang dirumuskan. Cara pengolahan data dilakukan secara deduktif yakni menarik kesimpulan dari suatu permasalahan yang bersifat umum terhadap permasalahan konkret yang dihadapi. Selanjutnya data dianalisa sehingga dapat diperoleh gambaran yang jelas tentang upaya hukum dalam perkara kepailitant menurut Undang-Undang Nomor 37 Tahun 2004.

\section{Pembahasan}

\section{Pengadilan Yang Berwenang Memutus Perkara Pailit \\ Dari rumusan ketentuan} pasal 3 dapat diketahui bahwa setiap permohonan pernyataan pailit harus diajukan ke pengadilan yang daerah hukumnya meliputi daerah tempat kedudukan hukum debitur, dengan ketentuan bahwa :

1. Jika debitur telah meninggalkan wilayah NKRI, pengadilan yang berwenang adalah pengadilan yang daerah hukumnya meliputi tempat kedudukan hukum terakhir debitur.

2. Jika debitur adalah Persero suatu Firma, maka pengadilan yang berwenang adalah pengadilan yang daerah hukumnya meliputi tempat kedudukan Firma tersebut.

3. Jika debitur idak bertempat kedudukan dalam wilayah NKRI tetapi menjalankan profesi atau usahanya dalam wilayah NKRI, maka pengadilan yang berwenang adalah pengadilan yang daerah hukumnya meliputi tempat kedudukan hukum kantor pusat debitur menjalankan profesi atau usahanya di wilayah NKRI.

4. Jika debitur merupakan badan hukum pengadilan di mana badan hukum tersebut memiliki kedudukan hukumnya sebagaimana dimaksud dalam anggaran dasarnya.

Ketentuan mengenai pengadilan yang berwenang diatas sejalan dengan ketentuan pasal 118 HIR yang menyatakan bahwa forum pihak yang digugatlah yang berhak memeriksa. Ini untuk memberikan keleluasaan bagi pihak tergugat untuk membela diri. $^{37}$

2. Upaya hukum dalam perkara kepailitan menurut Undang Undang Nomor 37 Tahun 2004.

Seperti diketahui bahwa upaya hokum merupakan langkah atau usaha yang diperlukan oleh pihak pihak yang berkepentingan untuk memperoleh keputusan yang adil.

${ }^{37}$ Ahmad Yani dan Gunawan Widjaja, op.cit 
Ada tiga macam upaya hokum yang dapat dilakukan dalam hal kepailitan yakni ; Perlawanan, Kasasi (Pasal 11-13 Undang Undang Nomor 37 Tahun 2004) dan Peninjauan Kembali (Pasal 14 Undang Undang Nomor 37 Tahun 2004).

a. Perlawanan

$$
\begin{aligned}
& \text { Perlawanan } \begin{array}{r}
\text { dalam } \\
\text { kepailitan diajukan } \\
\text { kepada }
\end{array} \\
& \text { putusan pernyataan pailit. }
\end{aligned}
$$

b. Kasasi

Upaya hokum lain yang dapat dilakukan terhadap putusan atas permohonan pernyataan pailit adalah kasasi ke Mahkamah Agung. Dengan demikian, terhadap keputusan pengadilan ditingkat pertama tidak dapat diajukan upaya hokum banding tetapi langsung dapat dilakukan upaya kasasi.

Pihak pihak yang dapat mengajukan upaya hukum, pada prinsipnya adalah sama dengan pihak yang dapat mengajukan permohonan pernyataan pailit, yaitu: Debitor, Kreditur, termasuk kreditor lain yang bukan pihak dalam persidangan tingkat pertama namun tidak puas atas putusan pernyataan pailit yang ditetapkan, Kejaksaan,Bank Indonesia, Badan Pengawan Pasar Modal ( BAPEPAM) dan Menteri Keauangan.

$$
\text { Permohonan kasasi }
$$
diajukan diajukan dalam jangka waktu paling lambat delapan hari terhitung sejak tanggal putusan yang dimohonkan kasasi ditetapkan, kemudian didaftarkan melalui panitera pengadilan niaga yang telah menetapkan putusan atas permohonan pernyataan pailit tersebut. Selanjutnya panitera akan mendaftar permohonan kasasi pada tanggal permohonan tersebut diajukan, dan kemudian kepada pemohon akan diberikan tanda terima tertulis yang ditanda tangani penitera dengan tanggal yang sama dengan tanggal penerimaan pendaftaran tersebut. Permohonan kasasi yang diajukan melebihi jangka waktu yang telah ditetapkan oleh undang undang (lebih dari delapan hari) bias berakibat pada “ dibatalkannya putusan kasasi”.

c. Peninjauan Kembali

Upaya hukum lainnya adalah peninjauan kembali oleh Mahkamah Agung terghadap putusan atas permohonan kepailitan yang telah mempunyai kekuatan hukum tetap.

Permohonan peninjauan kembali dapat dilkukan apabila :

1) Setelah perkara diputus ditemukan bukti baru yang bersifat menentukan yang pada waktu diperiksa di pengadilan sudah ada, tetapi belum ditemukan atau;

2) Dalam putusan hakim yang bersangkutan terdapat kekeliruan yang nyata.

Pengajukan permohonan peninjauan kembali dengan alasan tersebut, dilakukan dalam jangka waktu paling lambat 30 hari terhitung sejak tanggal putusan yang dimohonkan peninjauan kembali memperoleh kekuatan yang tetap. Permohonan peninjauan kembali bias disampaikan kepada 
panitera pengadilan niaga yang memutus perkara pada tingkat pertama. Panitera yang menerima permohonan PK akan mendaftar permohonan tersebut kepadfa pemohon diberikan tanda terima tertulis yang ditanda tangani panitera dengan tanggal yang sama dengan tnggal permohonan didaftarkan. Selanjutnya pihak termohon dapat mengajukan jawaban terhadap permohonan PK yang diajukan, dalam waktu 10 hari terhitung sejak tanggal permohonan didaftarkan dan panitera wajib menyampaikan jawaban tersebut kepada panitera Mahkamah Agung, dalam jangka waktu paling lambat 12 hari terhitung sejak tanggal permohonan didaftarkan.

\section{E. Penutup}

\section{a. Kesimpulan}

Berdasarkan dari hasil
pembahasan di atas kesimpulan
bahwa:

1. Bahwa setiap permohonan pernyataan pailit harus diajukan ke pengadilan Niaga yang daerah hukumnya meliputi daerah tempat kedudukan hukum debitur, dengan ketentuan bahwa :

a. Jika debitur telah meninggalkan wilayah NKRI, pengadilan yang berwenang adalah pengadilan yang daerah hukumnya meliputi tempat kedudukan hukum terakhir debitur.

b. Jika debitur adalah Persero suatu Firma, maka pengadilan yang berwenang adalah pengadilan yang daerah hukumnya meliputi tempat kedudukan Firma tersebut.

c. Jika debitur idak bertempat kedudukan dalam wilayah NKRI tetapi menjalankan profesi atau usahanya dalam wilayah NKRI, maka pengadilan yang berwenang adalah pengadilan yang daerah hukumnya meliputi tempat kedudukan hukum kantor pusat debitur menjalankan profesi atau usahanya di wilayah NKRI.

d. Jika debitur merupakan badan hukum pengadilan di mana badan hukum tersebut memiliki kedudukan hukumnya sebagaimana dimaksud dalam anggaran dasarnya.

2. Bahwa uapaya hukum dalam perkara kepailitan ada tiga macam upaya hukum yang dapat dilakukan yakni ; Perlawanan, Kasasi dan Peninjauan Kembali (PK). Perlawanan dalam kepailitan diajukan kepada pengadilan yang menetapkan putusan pernyataan pailit. Upaya hukum kasasi diajukan ke Mahkamah Agung, dengan demikian, terhadap keputusan pengadilan ditingkat pertama tidak dapat diajukan upaya hukum banding tetapi langsung dapat dilakukan upaya kasasi. Upaya hukum peninjauan kembali oleh Mahkamah Agung terghadap putusan atas permohonan kepailitan yang telah mempunyai kekuatan hukum tetap dengan alasan apabila:

a. Setelah perkara diputus ditemukan bukti baru yang bersifat menentukan yang pada waktu diperiksa di pengadilan sudah ada, tetapi belum ditemukan atau;

b. Dalam putusan hakim yang bersangkutan terdapat kekeliruan yang nyata.

b. Saran

Dalam penulisan karya ilmiah ini dapat disarankan: 
1. Dalam memutus perkara kepailitan hakim diberikan kewenangan oleh Undang Undang untuk memutus perkara, sehingga putusan diharapkan yang seadil adilnya..

2. Upaya hukum dilakukan oleh pihak yang merasa tidak puas dengan putusan pengadilan tingkat pertama, maka Mahkamah Agung diharap dapat memutus perkara kasasi maupun peninjauan kembali secara cepat dan jangan sampai berlarit larut sehingga secepatnya ada kepastian hukum bagi para pihak.

\section{DARTAR PUSTAKA}

\section{LITERATUR:}

Ahmad Yani dan Gunawan Widjaya, Seri Hukum Bisnis Kepailitan. Raja Grafindo Persada, Jakarta. 2004. Johnny Ibrahim, Teori Metode Penelitian Hukum Normatif, Banyu Media Publishing, Malang 2005

Hadi Setia Tunggal, Undang-Undang No. 37 Tahun 2004 Tentang Kepailitan dan
Penundaan Kewajiban Membayar Hutang, Havarindo, Jakarta, 2005.

Kartini Mulyadi dan Gunawan Widjaya, Pedoman Menangani Perkara Kepailitan. Raja Grafindo Persada Jakarta. 2003:

Munir Fuadi, Hukum Pailit Dalam Teori dan Praktek, Citra Aditya Bhakti 2002

R. Soekardono, Hukum Dagang, jilid I, Dian Rakyat; Jakarta 1993.

Soebekti, Pokok-Pokok Hukum Perdata, Intermasa, Jakarta 1994.

Viktor M. Situmorang, Hendri Soekarso, Pengantar Hukum Indonesia. Rieneka Cipta, Jakarta 1994.

\section{PERUNDANG UNDANGAN:}

Kitab Undang Undang Hukum Perdata (KUHPdt)

Kitab Undang Undang Hukum Acara Perdata (KUHAPdt)

Undang Undang Nomor 37 tahun 2004 tentang Kepailitan dan penundaan kewajiban pembayaran utang. 